\title{
Agency Response to Female Victims of Domestic Violence: The British Approach
}

\author{
Janice Joseph
}

Domestic violence is often referred to as an 'invisible crime' and is an epidemic of global
proportions. It occurs irrespective of religion, race or ethnicity, sexuality, age, or disability.
It has devastating physical, emotional, financial, and social effects on women, children,
families, and communities around the world. The economic cost to society is also immense.

Keywords: Invisible Crime; Global Proportions; Economic Costs

Traditionally, like most countries, Britain ignored the problem of domestic violence. However, in recent years the government has passed a series of legislation, strategies, and policy initiatives to combat domestic violence. This paper examines how agencies respond to victims of domestic violence (including ethnic minorities). ${ }^{1}$ The first part of this paper focuses on legislative and policy responses to domestic violence in Britain and the second part presents qualitative data from interviews with statutory and voluntary sector personnel in Coventry and London.

Any attempt to assess and respond to future policies and initiatives will depend on the definition of domestic abuse. The term 'domestic violence' is used to describe violent acts that occur in domestic settings and includes spouse abuse, any form of child abuse or abuse of other family members, and even abuse involving (in the case of Western societies) same sex relationships. However, it is male violence against women in intimate relationships that has dominated the discussion on domestic violence. Thus the term domestic violence implies a relational dimension: the man is known to the woman and is currently or has formerly been in a relationship with her.

Janice Joseph is a Professor in the Criminal Justice Program at Richard Stockton College of New Jersey. Correspondence to: Janice Joseph, Richard Stockton College of Criminal Justice, Criminal Justice Program, Jim Leeds Road, Pomona, NJ 08240, USA. Email: janice.joseph@stockton.edu

ISSN 1478-601X (print)/ISSN 1478-6028 (online) @ 2006 Taylor \& Francis DOI: $10.1080 / 14786010600615983$ 
According to the Home Office, ${ }^{2}$ domestic violence is:

Any violence between current and former partners in an intimate relationship, wherever and whenever the violence occurs. The violence may include physical, sexual, emotional and financial abuse. (Home Office, 2003, p. 6)

\section{The Nature and Extent of Domestic Violence in Britain}

Domestic violence is one of Britain's biggest crime problems since one woman in four experiences domestic violence and every 6-20 seconds an incident of domestic violence occurs-overwhelmingly against women (Seymour, 2002). It is estimated that in the $\mathrm{UK},{ }^{3}$ police officers receive a call from a victim of domestic violence every minute, and this leads to police receiving an estimated 1,300 calls each day or over 570,000 each year (Stanko, 2000). An average of two women every week are killed in the UK by a current or former partner. Domestic violence incidents make up $25 \%$ of all violent crime in the UK (Home Office, 2001).

Research indicates that one out of every six homeless families is escaping domestic violence (Home Office, 1999). There are children in half of the households where there is domestic violence, and it is also estimated that between one-third and twothirds of children live in homes where their mother is being abused (Home Office, 2001). During 2002, 25,000 UK children stayed in refuges ${ }^{4}$ with their mothers who were fleeing domestic violence, and more than 120,000 were supported by domestic violence services. In Britain, domestic violence is the least likely violent crime to be reported to the police, and just under one-third of incidents were reported. On average, a woman is assaulted 35 times before she reports it to the police (Home Office, 2001).

Walby (2004) estimates that domestic violence is costing Britain the enormous sum

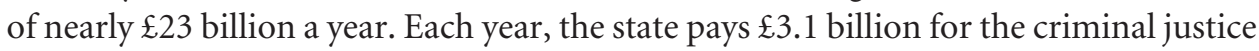
system, the health system, social services, social housing, and legal aid bills to support victims. Lost economic output is estimated at $£ 2.7$ billion, over half of which is borne by employers. In terms of pain, suffering and loss of employment, housing or health, the cost amounts to about $\mathfrak{E} 17$ billion.

\section{Responses to Domestic Violence}

\section{Policy and Legislation}

Scotland Yard recently encouraged the government to enact new laws that would force doctors, social workers, and other professionals to report incidents of domestic violence. The Scotland Yard proposal would make it mandatory for professionals who are aware of such incidents to inform a (new) risk assessment panel. The panel's assessment could lead to swift police action to deal with the most dangerous offenders, anger management therapy for others, and timely help for victims. This recommendation was based on research that showed that, in many cases of domestic murders, health workers, housing officers, and others often knew about previous assaults but did not 
share the information with one another. This has resulted in the deaths of some victims (Hyder \& Cowan, 2004).

In 2003, the British government introduced the Domestic Violence, Crime and Victims Bill 2004 which involved the biggest overhaul of domestic violence legislation for 30 years. It is a key part of the government's aim of putting victims at the heart of the criminal justice system. The Bill is intended to ensure an effective police response when victims report domestic violence, and makes sure that the civil and criminal laws offer the maximum protection to all victims. The Bill will:

- Make common assault an arrestable offense.

- Trigger multi-agency reviews in cases of domestic murder, as happens with child killings.

- Make breaching non-molestation orders an arrestable offense with up to five years in jail.

- Establish a register for domestic violence offenders, forcing them to tell police when they change their addresses.

- Give same sex couples the same protection as heterosexual couples.

- Provide a new offense for causing or allowing the death of a child or vulnerable adult.

- Introduce a ban on the media naming victims of alleged domestic violence in court cases in an effort to encourage more people to come forward with complaints.

- Establish a victims' commissioner to speak up for the interests of victims (Crown, 2005).

In July 2002, the Homelessness Act was passed and the new Priority Need Order was brought into effect. The Act gives greater protection to those with a priority need for housing. It also extends the priority list to include 16 and 17 year olds and 18-21 year olds needing care, as well as those fleeing violence. The Homelessness Directorate allocated $£ 125$ million in 2002-2003 to help local authorities meet this challenge, and many have used some of this money to form partnerships with local women's aid groups to develop innovative schemes that can reduce and prevent homelessness caused by domestic violence. The Homelessness Directorate and Comic Relief have

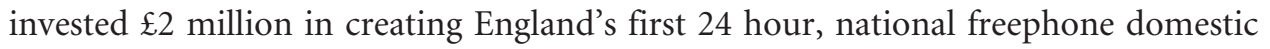
violence helpline, and $\mathfrak{E} 7$ million of capital funds would be invested to extend the national network of women's refuges in England (Crown, 2003). This Act is the most important piece of legislation on housing and homelessness since the Housing Act 1996. Under the Housing Act of 1996, the local authority has a temporary, but renewable, two year duty to house certain applicants, such as those who are homeless or threatened with homelessness such as those experiencing domestic violence (Women's Aid Federation of England, 2004a).

Part IV of the Family Law Act 1996 provides for a single set of civil remedies to deal with domestic violence and to regulate occupation of the family home, through two specific types of order: the occupation order and the non-molestation order. These remedies are available at all levels of the court system (magistrates, county, and High) with jurisdiction in family matters. They are: 
- Occupation orders which decide who is allowed to occupy the home, and can direct another party to leave the home.

- Non-molestation orders which prevent the respondent from molesting the applicant or a relevant child. It can prohibit particular actions and behavior or molestation in general (Crown, 1996; Women's Aid Federation of England, 2004b).

When the court makes an occupation order or non-molestation order and it appears to the court that the respondent has used or threatened violence against the applicant, then the court must attach a power of arrest unless it is satisfied that the applicant will be adequately protected without such a power (Crown, 1996). In addition, if a woman is in immediate danger, she can apply to the court the same day for an 'ex-parte' (emergency) order without her partner being there. She will then have to go back to court, once he has been served with notice of the order, for a full hearing (an 'inter-parties' hearing). A problem with enforcing an ex-parte injunction is that it does not come into force until a copy of the order has been physically handed to the violent partner. If the partner makes himself scarce and avoids being served the order, there can be a delay between the injunction being made and being enforced (BBC, 2005).

\section{Multi-agency Approach}

In 1995, the British government encouraged a more coordinated multi-agency/interagency response to tackling the problem of domestic violence, especially through the setting up of a local domestic violence forum. It also outlined the roles and responsibilities of the various agencies involved in tackling domestic violence and provided a list of contact points for those seeking further information. This multi-agency includes local authority departments (including housing, social services, and education), police, probation, health services, refuges, women's support and outreach projects, community projects, and the voluntary sector. There are now over 200 multi-agencies in England and Wales working together in local communities to tackle domestic violence (Home Office, 2000a, 2000b).

\section{Criminal Justice}

Until recently, domestic violence was frequently defined by police as 'rubbish work' and was seen as a private matter, not 'real' violence. The sympathies of a predominantly male police force were often with the violent man/husband. In 1990, the Home Office called on police forces to develop proactive policies and operational interventions to deal with domestic violence. It recommended that officers develop an improved understanding of, and response to, victims of domestic violence (Hanmer \& Griffiths, 2000). It also entrusted the officer with the immediate duty of securing the protection of the 'victim' and any children, and then to consider action against the 'offender.' Officers do not need a warrant to arrest someone whom they suspect is about to or who has committed an arrestable offense; nor do they need to witness an assault (Home Affairs, 1990). In many forces, Domestic Violence Units have been established or Domestic 
Violence Officers appointed, with the responsibility of providing support and advice to victims and helping them get in touch with relevant outside agencies (Hanmer \& Griffiths, 2000). Under this new policy, officers are expected to:

- protect victims and children from further attack;

- treat domestic violence as seriously as other forms of violence;

- use the powers of arrest;

- understand the dangers of seeking reconciliation between assailant and victim (Women's Aid Federation of England, 2004c).

The Crown Prosecution Service (CPS) is responsible for prosecuting people in England and Wales charged with a criminal offense. In November 2001, the CPS issued a revised policy on prosecuting cases of domestic violence which focuses on safety, support, information for victims, and a closer civil/criminal interface. The new policy provides practical guidance on how to proceed if a victim withdraws support for the case. The CPS also stated that it will consider every case carefully and sensitively and its decisions will be objective but made within a framework that promotes safety and support for the victim. It also established a national Network of CPS Domestic Violence Co-coordinators in November 2001 and the aims of this network include: (a) facilitating implementation of the new policy; (b) promoting the exchange of information and good practice; and (c) identifying and addressing problems (Women \& Equality Unit, 2004).

In 1999, Britain established its first domestic violence court as a pilot project in Leeds. The aim of the domestic violence court is to encourage victims to report incidents and to ensure that the perpetrators of violence are dealt with effectively. Since then, other cities in England have established domestic violence courts (see BBC News, 2002).

The National Probation Service has been organizing domestic violence offender programs for a number of years, often in partnership with the voluntary sector. In addition, the National Probation Service and the Prison Service have been working together to ensure an effective and consistent approach for dealing with domestic violence offenders. More than 200 probation and prison staff have been trained in the Spousal Assault Risk Assessment Tool (Women \& Equality Unit, 2004).

\section{Refuges}

Women's refuges provide safe temporary accommodation for victims of domestic violence. They provide a high level of casework support, practical help, advice, and counseling, although most refuges do not take women that have a current drug or alcohol problem.

Women's Aid Federation of England (Women's Aid) is the national charity working to end domestic violence against women and children. The first Women's Aid groups were set up 30 years ago in response to women's desperate need for a place to stay with their children, where their violent partners could not find them. Those early refuges were operated entirely on the voluntary labor of committed women, activists, and survivors. The mission of Women's Aid is to: 
50 J. Joseph

- Offer support and a place of safety to abused women and children by providing refuges and other services.

- Empower women affected by domestic violence to determine their own lives.

- Recognize and meet the needs of children affected by domestic violence.

- Promote policies and practices to prevent domestic violence.

- Raise awareness of the extent and impact of domestic violence in society (Women's Aid Federation of England, 2004d).

Presently, Women's Aid in England and Wales coordinates and supports an England-wide network of over 300 local projects, over 500 refuges, helplines, outreach services, and advice centers. In the year 2001-2002, the national network of domestic violence service providers supported a total of 143,337 women and 114,489 children (with over 40,000 women and children staying in their refuges). A further 35,000 individuals called the Women's Aid 24 hour National Domestic Violence Helpline for information, support, and access to local refuge and other domestic violence services (Women's Aid Federation of England, 2004d).

Hostels

If women fleeing domestic violence agree to be temporarily accommodated in a hostel, the priority is to find a women-only hostel. A woman can go to a women-only hostel directly without approaching a Homeless Person Unit. When local authorities make use of general-purpose hostels, they try to place women and children in the most appropriate hostel provision, since many general-purpose hostels lack suitable arrangements for victims of abuse. The hostels usually have secure accommodation or an address that is kept secret.

\section{Research Project}

The research for this study was conducted mainly in the autumn of 2003 in Coventry and London, England. The aim of the research was to gain an insight into agency response to victims of domestic violence in Britain. There were two main sources of data gathering in the project: (1) interviews with agency personnel, and (2) information from agency reports.

\section{Agency Survey: Interviews with Personnel in Statutory Voluntary Agencies}

The study is based on in-depth interviews with 16 professionals from 10 statutory and voluntary agencies and from the annual reports and brochures of agencies. These agencies include the domestic violence partnership forum (multi-agency), domestic violence units, a refuge, hostel, and ethnic minority agencies in Coventry and London.

\section{Methodology}

In my research, I chose to interview people who work with battered women because they had extensive knowledge and experience working with female victims of 
domestic violence. To gain access to people who work with battered women, I gathered contact information on the relevant agencies and called these agencies. After several telephone calls, I was able to schedule interviews with the directors of the various agencies. I was surprised at the ease at which I was able to acquire interviews, especially since I was an outsider from the USA, but my status as a faculty member of Coventry University made the difference. In fact, these professionals welcomed any comparative information on domestic violence between the USA and Britain that I could offer them. Most of the professionals from the agencies viewed themselves either as activists or practitioners who were concerned with the practical experiences of their clients.

I used several strategies to make the interviews successful. First, during the interviews, I viewed myself on the same level as my respondents. In other words, the hierarchical relationship that often exists between the researcher and the research subjects was eliminated. Second, although it is often difficult for a researcher to remain value free, I tried to be cognizant of the importance of not making assumptions and conclusions about each agency and those being interviewed. I basically entered the interview session with an open mind, and this facilitated my acceptance of all the responses from my respondents. Third, I made presentations to employees of two of the (ethnic minority) agencies as well as attended some of their social functions. I viewed this as a form of negotiation and reciprocity since I viewed my relationship with these agencies as symbiotic rather than one way; these agencies benefited from my service and presence and I benefited from their employees' participation in my research. I believe that the strategies I used were of paramount importance in obtaining detailed information from my respondents. In fact, I was able to interview the directors of two of the ethnic minority agencies several times.

The interviews focused on the directors' professional experiences working with female victims of domestic violence and their perceptions of domestic violence in general. The interviews were guided by the following issues: history of the agency, goals of the agency, services/programs of the agency, clients, problems serving victims of domestic violence, and perceptions of domestic violence. The interviews were conducted mostly with one person, but in a few cases there were two or more respondents. The average interview lasted over two hours, and I was surprised and pleased with their willingness to speak with me for such a long period of time. Their hospitality was extraordinary. Collectively the interviews provided a more comprehensive view and understanding of the dynamics of domestic violence in Britain.

\section{Statutory Agencies}

The multi-agency/interagency on domestic violence in Coventry was established in 1990 , and it is a partnership between the voluntary and statutory sectors. It is chaired by an officer from Coventry City Council and the partnership is supported by the Domestic Violence Coordinator who is a paid full-time employee. It is the strategic multi-agency partnership which coordinates Coventry's response to domestic violence. The membership comprises of 22 agencies and a wide range of workers, managers, and 
policy makers from various voluntary and statutory sector organizations including local women's refuges and domestic violence projects.

Since its inception, the Coventry Domestic Violence Partnership has established a Domestic Violence Project for African Caribbean women; produced an Information Guide and Directory for the city, distributed leaflets and posters about domestic violence, presented a video promotion in doctors' practices, commissioned and published a research report called 'Voices of Children Witnessing Domestic Violence: A Form of Child Abuse.' It has also formulated the City Council Policy and Guidelines, and organized two major conferences.

Because the multi-agency/inter-agency approach is relatively new in Britain, little is known about the practical problems involved in inter-agency work or how effective it is in dealing with the complex problems faced by many victims of domestic violence. However, information from the agency revealed the following:

- Each agency in this partnership has different roles but these have not always been clear to the agencies. In addition, individual constraints and priorities necessary to develop a successful partnership seem to be ignored by some agencies in the forum (partnership).

- There is interagency conflict between the voluntary and the statutory agencies (police and courts) which tend to dominate the forum. In fact, the police appear to be the lead agency in this forum. There are clearly power imbalances in this agency and this reduces the potential for developing true collaborative partnerships.

- There were complaints of inadequate resources. Respondents indicated that the agency could be more effective if there were more resources.

- The demand to participate in partnership meetings and multi-agency work puts a great financial strain on voluntary organizations whose members participate in the multi-agency.

It does appear that, although the multi-agency/inter-agency forum was designed to provide a comprehensive service to domestic violence victims, it has not been very effective because of the problems that plague the agency. These organizational gaps in the structure indicate that there is a need for increased support for this agency and closer collaboration between the statutory and the voluntary agencies.

In Coventry, there are three police departments, and each department has Domestic Violence Liaison Officers, all of whom are females. I interviewed two of these officers because one of the officers was incapacitated (she had surgery) during the time of the survey.

The Domestic Violence Liaison Officers who were interviewed were relatively new to the position. One had been in the position for two years, and the other three years. They had special domestic violence training. The Domestic Violence Liaison Officer has a number of responsibilities, working in partnership with many other statutory and voluntary agencies. She acts as a liaison between the department, social agencies, and the victim and coordinates all the domestic violence cases. Although she does not visit the crime scene, she examines the domestic violence cases every day to ensure that the officers who investigated these cases have done their jobs adequately. She interviews 
victims and also monitors the perpetrators in the cells. If children are involved, she has to contact social services so the children can be placed on the 'risk' register and removed from the home immediately. If the perpetrator is taken to court, she also monitors court cases, contacts solicitors for the victims, writes letters of support for housing moves, makes referrals for benefits and social services, and liaises with probation offenders.

The respondents informed me that officers in the departments have domestic violence training and, when they investigate domestic cases, they must wear padded vests (unlike in the USA where they use bullet proof vests) because officers have been stabbed or attacked by assailants and even victims.

The interviewees reported that between 20 and $30 \%$ of the calls to the department are domestic violence calls, and the departments compile a list of the top 20 homes. They also noted that between 30 and $40 \%$ of the incidents involve repeat victims and perpetrators. The most recent form of domestic violence is domestic stalking in which perpetrators use mobile/cell phones to text message victims. One officer reported that there was a case in which the perpetrator sent 50 harassing text messages to the victim in one day, and she had to get an injunction.

The officers noted that most of the victims are white. They see very few ethnic minorities—blacks and Asians-because most are refugees, asylum seekers, or illegal immigrants and are, therefore, afraid that they will be deported if they report the violence. Moreover, these ethnic minority women are reluctant to report their abusers because they do not want them to go to prison. One officer reported that:

\begin{abstract}
A black female had her hand severed as she grabbed the knife her husband was using to cut her throat. Although the husband attempted to kill her, she was very reluctant to provide the police with adequate information to make an arrest. She was afraid that he was going to go to prison for a very long time.
\end{abstract}

The police departments have installed panic alarms, which are linked to the departments, in some of the victims' homes. The women can simply press the alarm when they feel that they are in danger, and then the departments will record all the sounds in her surroundings. These alarms alert the police who can then respond accordingly. The police department also provides some victims with track-o-phones which they carry with them at all times. If the victim feels threatened, she can press a button on the device, and the police can identify her exact location and find her immediately. One of the liaison officers showed me the track-o-phone, which appears to be a useful device for these victims. The officers also agree with the policy of naming and shaming (in newspapers) domestic violence offenders as part of a campaign against abusers and to bring attention to the crime. In fact, during the time that I was in Coventry, photographs, names, and criminal history of abusers were printed on the front page of a local newspaper.

The liaison officers provided me with some insight into the operation of the court system. Many of the cases do not go to trial because of plea bargaining. However, when the cases go to trial, victims are informed, but (unlike in the USA) victims do not have to testify. Cases can proceed without the victims' testimony or assistance. However, the 
Crown Prosecutor Service gains the cooperation of victims by threatening them with an arrest if they do not cooperate. During the court cases, the victims, especially vulnerable and intimidated victims, can be videotaped/or interviewed on video as well as cross-examined over a video link.

The liaison officers expressed frustration with the response of judges to domestic violence cases. They reported that judges give lenient sentences to batterers. One officer remarked: 'It is difficult to get through to judges. They are poorly trained and they do not take domestic violence seriously.'

In general, these liaison officers take their jobs seriously, but they seemed overwhelmed with the quantity of work and the responsibilities with which they are entrusted. One officer stated that she is kept extremely busy and had to work late at night and even on weekends. She felt that her job was a large enough job for two officers.

\section{Statutory Agencies}

In Coventry, there is only one refuge which is a member of the Women's Aid Federation of England (WAFE) and funded by the British government. This refuge had five project workers (at the time of the interview), and the services that the refuge offers have expanded over the years. However, the number of bed spaces available is still small. It provides shelter for 17 women and 35 children.

A number of different agencies refer women to the refuge in Coventry. They are referred mainly by the National WAFE Helpline, Women's Aid Helpline, social services departments, police departments, or by victims directly telephoning the refuge. The refuge could transfer the women across the country as well as accepting women from out of town. Fifty percent of its intake is from outside of the city.

As a temporary accommodation, the refuge can accommodate women from a few days to a few months. The refuge provides a range of emotional and practical services for victims, and assists with their benefit claims, care plan and legal counsel, and makes referrals to other agencies. There is no time limit, and a few victims stay as long as nine months. However, the Director stressed that it is not healthy for the women to be in the refuge more than four months. However, no woman is asked to leave without new accommodation available for her. Most leave the refuge within seven weeks, and the employees in the refuges visit the women after resettlement.

In 2002, the refuge served 130 women but, at the time of the interview (October 2003), there had been an increase; it had already served 160 women. The majority of the victims served by this agency are of dual-heritage women-from two ethnic backgrounds-and African-Caribbean women. The Director stressed that she attempts to employ ethnic minority women and that the agency uses a multifaceted approach to domestic violence. She also emphasized the fact that she does not believe in culturally specific agencies.

The only hostel in the city has been in operation for 25 years. It provides services to women, with or without children, experiencing domestic violence. The agency provides safe houses and makes referrals inside and outside Coventry. It coordinates with other agencies, such as housing departments and police, to assist the victims. It has 
six beds for women and children who are fleeing domestic violence. The victims can stay up to a year in the hostel, but the agency tries to find accommodation for the women and children as quickly as possible.

The locations of hostels in Britain are confidential and use CCTV cameras. The strictness of the agency was evident when I went to conduct the interview because, although I identified myself and had a prior appointment, the employees were reluctant to let me into the hostel at first. When they finally let me in, they told me that they have to be very careful because perpetrators use other women to get into the hostel. Women who give out the address of the hostel are evicted immediately.

There is no waiting list, and the hostel tries to house the victims the same day that they contact the agency. A wide range of women who are fleeing domestic violence use the service including refugees and asylum seekers who cannot work. Many of the women have substance abuse and other problems and so they have to be referred to multiple agencies.

\section{Ethnic Minority Agencies}

The number of ethnic minorities in Britain is small—only 1 in 15 persons-yet it appears that the domestic violence rate is high among these groups. For example, research carried out in the Midlands police region (where Coventry is located) in 2000 showed that almost 4,000 Asian women reported being abused by their partners in the previous year, but Asian community workers indicate that it could be higher as many women do not come forward (BBC News Online: UK, 2001). A disproportionate number $(40 \%)$ of the women in refuges in Britain are from ethnic minority communities, and services for ethnic minority women appear to be patchy, inconsistent, and often dependent on individuals or one particular organization (Home Office, 1999).

The ability of mainstream services to respond adequately and effectively to diverse and specific groups has been questioned since the majority of service agencies mirror the ideals and interests of the majority group. In many cases, the pluralist nature of British society is not reflected in the mainstream agencies. Consequently, there are those who argue there should be culturally sensitive agencies that cater to the needs of ethnic minorities. In Coventry, there are two ethnic minority agencies; one serves Asians and the other women of African descent, especially African Caribbean. Within these two ethnic minority organizations there are projects that serve female victims of domestic violence. I conducted interviews with the directors and gathered information from these two organizations. In December 2003, I went to London and interviewed two co-directors of an agency which focuses on abused African women. In May 2004, I also conducted a group interview with several directors of agencies (in London) that serve female victims (from Africa) of violence.

There are common themes that emerged from my interviews with the directors of the ethnic minority agencies (in Coventry and London). They indicated that many of the women they serve are refugees, asylum seekers, or 'immigrants in transition' (awaiting the outcome of their application), and the media portrayal of refugees, asylum seekers, and ethnic minority immigrants is negative. They noted that these 
ethnic minority women who face violence from their husbands may be denied the normal protection from state authorities because, if they leave their abusive husbands, they face the risk of deportation to their homelands. They may also have no means of financial support if they leave the marital home, since they may not be entitled to basic welfare benefits. In addition, if the partner separates or divorces before her 'indefinite leave' to remain in the UK has been granted, the application for settled status will almost certainly be refused. Under these circumstances, the victim has two options: to live with domestic violence or face deportation. Consequently, these women choose to remain with their batterers. One director gave an example of how problematic it is to leave their abusers. She remarked that:

\footnotetext{
A victim, who was awaiting her immigrant status in England, got tired of being abused by her husband, and so she reported him to the police. When he was arrested he simply told the police that he did not know who she was. After an investigation, it was discovered that she was a refugee and so she and her five children (the batterer was the father) were deported to their native country in Africa.
}

Another theme echoed throughout the interviews with the professionals who work with ethnic minority women was the reluctance of these victims to leave their abusers because they have to protect their families back home. If they break up their families by leaving the abusers, people in their home communities will 'point their fingers' at them and their relatives/families in their country of origin, complaining that the woman is no good because she broke up the marriage. One director referred to this as 'dual victimization'-being in an abusive relationship and having family members of the abused women in their native country ostracized by the community.

Another issue highlighted in the interviews was that these women are reluctant to report their abuse to the police. There are several reasons for this. In some instances, they view the police as agents of oppression and as the enemy. This is particularly true of women from Asia and Africa, many of whom had endured physical abuse (directly or indirectly) from the police in their home countries. Some ethnic minority women are also reluctant to call the police because their culture and tradition stigmatize the reporting of domestic abuse and they do not want to be ostracized by their ethnic communities. There is the feeling that this will bring shame on the family. One director reported that:

\footnotetext{
There was an incident in which one of the workers in her agency was abused, and another worker called the police. The victim stopped speaking to the other worker. The victim told the coworker, who called the police, 'one does not call the police on a black man.'
}

Another recurring issue identified by these interviewees is the difficulty in providing counseling for these victims, especially those from Asia and Africa. One director remarked that it is a complex task to counsel these women because, even if they are from the same region of the world, they do not form a homogenous group. Among each group, there are major differences in language, cultural practices, family history, political experiences, and social class status, and this makes the counseling of these victims very challenging. In addition, many of them do not have the appropriate tools (for example, English or relevant information) to 'navigate' the system. It is often 
difficult to establish rapport with and empower these victims. In effect, the cultural barriers, pre-migration and post-migration experiences, and individual resistance to change impede the counseling process. Added to this is the fact that some of the domestic violence victims also have multiple problems such as mental illness, drug addiction, HIV, and other physical and psychological problems.

In general, these professionals who serve ethnic minority victims expressed frustration because they felt that not enough was being done to support and help ethnic minority female victims of domestic violence. However, in 2004, the government launched reforms aimed at protecting black and ethnic minority women who are victims of domestic violence issues (see BBC News/UK, 2004) and in 2005, the Home Office issued a report which provided new guidelines to those practitioners who directly work with female victims of domestic violence who are from black and other minority ethnic communities (Parmar, Sampson, \& Diamond, 2005). Although the government is trying to provide services for the victims of domestic violence in the ethnic minority communities, it appears that few preventive measures are implemented in these communities to stop the violence in the first place.

\section{Professionals' Perceptions of Domestic Violence}

Most of the professionals who were interviewed adopted a relatively wide definition of domestic abuse which included, not only physical and sexual assault, but also emotional and psychological abuse. One interviewee remarked:

One cannot separate physical abuse from emotional and psychological abuse. They are all part of the same continuum. Very often the physically abused victims are often abused emotionally and psychologically as well.

A small minority of interviewees adopted narrower definitions of domestic abuse, but most, however, admitted that the impact of emotional and psychological abuse were more difficult to recognize and harder to prove in court than physical abuse. Most of the professionals whom I interviewed reported that they believed that domestic violence was on the increase in Coventry and London. Most suggested that the overall increase in domestic violence is related to increased use of drugs (legal and illegal), increased family stress, and the impersonal nature of the communities (neighbors do not know each other). However, many emphasized the fact that there is a greater general awareness of domestic violence, and people are now more willing to report it. There was also a feeling among the professionals that, as more women become aware of their rights, they will be unwilling to accept this form of victimization.

There was a widely held view among the interviewees that more service, training, and awareness-raising are needed, not only for those professionals who are on the frontline of domestic abuse and have to deal with the consequences of it on a daily basis, but also for those who perform a gatekeeping role. Many were of the opinion that professionals in statutory agencies, such as the police and the courts, do not understand the dynamics of domestic violence and cannot comprehend why some battered women make the decisions that they make. One interviewee remarked: 
The police do not understand why the woman wants to stay with the abuser or says that she still loves him after he has physically hurt her so many times.

All of the interviewees agreed that accessible and affordable services for the victims of domestic violence are vital. They identified many deficits in the support systems for abused women. They were highly critical of the lack of refuges for battered women. One interviewee remarked that 'there were more animal shelters in Britain than refuges and this was a shame.' They also made several suggestions to reform the system. These included:

- More cooperation between the various agencies. Too often the agencies dealing with domestic violence operate segmentally and haphazardly.

- Dissemination of more information on domestic violence so that members of the community can recognize and prevent domestic violence.

- Identification of families and women at risk for domestic violence. Too often professionals are not aware of the risk factors of domestic violence and, therefore, may not be able to prevent it happening to the women they service in a professional capacity (such as counseling for drug addiction).

- Collection of data on the nature and extent of domestic violence in cities in Britain so that appropriate services and prevention measures can be implemented.

- Holistic services and support systems are needed. Most of the services are unidimensional, but often these victims are facing multiple victimization. What is needed is a pluralist approach in the services offered to battered women.

- Culturally specific services for ethnic minorities, lesbians, specific religious groups, and immigrants.

In general, these professionals seem to be doing an admirable job given the limited resources that are available to them. They have tried to understand the problems and dilemmas facing victims in abusive situations. Many are also aware of the interrelationship between physical, psychological, and emotional abuse, and the work that is needed to be done to eliminate the attitudes toward domestic violence.

\section{Conclusions}

In recent years the phenomenon of domestic violence has received a great deal of governmental attention in Britain. However, based on the issues raised in the study, the services remain inadequate either because the human and material resources are insufficient or because inter-agency services are not well coordinated. It is, therefore, important that policy makers increase the statutory and voluntary services for female victims of domestic violence. Attempts should also be made to improve the dissemination of information, and anti-domestic violence campaigns should be tailored to the local communities. It is imperative to change the attitudes of the public about male and female gender roles, domestic violence, and victims and perpetrators of domestic violence.

Although the ethnic minority population in Britain is relatively small, it does appear that domestic violence is relatively high among them. It is, therefore, imperative that 
more specialist services for ethnic minorities be established. These should be culturally sensitive and culturally appropriate for these groups. More importantly, attempts should be made to prevent the victimization of women in the homes in these communities.

A significant obstacle to the elimination of domestic violence is the lack of a comprehensive approach to the problem. Domestic violence is a complex problem that requires a multi-dimensional approach. Although domestic violence takes place in private, it has public consequences. It is also considered a violation of basic human rights, undermines a woman's dignity and equality, and occurs within the context of the subordination of women. To fully address the issue of domestic violence, policy makers must adopt a multi-pronged strategy that reflects an awareness of the interlocking structural and contextual factors that underlie this problem. This approach must be fourfold; it should address the root and multifactorial causes of the problem, empower women, provide services to victims, and severely punish perpetrators for their behavior. Such a holistic approach to domestic violence will be the only realistic way to end this serious social problem.

\section{Notes}

[1] In Britain, the term 'ethnic minorities' is commonly used to refer to people born in the Asian and African continents and the Caribbean and their descendants.

[2] The Home Office dealing with criminal justice, prisons, police, and other non-criminal justice issues in Britain.

[3] The term 'Great Britain' (Britain) includes the countries of England, Scotland, and Wales and the UK includes Great Britain and Northern Ireland. The terms Britain and UK will be used interchangeably.

[4] Britain uses the word 'refuge' instead of 'shelter' but they are basically the same type of agency.

\section{References}

BBC. (2005, March 25). Hitting home-Practical help: Your legal rights. Retrieved from http:// www.bbc.co.uk/health/hh/practical14.shtml

BBC News. (2002, October 3). Domestic violence costs city $£ 10 m$. Retrieved from http:// news.bbc.co.uk/1/hi/england/2294217.stm

BBC News Online: UK. (2001, February 8). More Asians reporting violence. Retrieved from http:// news.bbc.co.uk/1/low/uk/1160177.stm

BBC News/UK. (2004, November 15). Help for minority women victims. Retrieved from http:// news.bbc.co.uk/2/low/uk_news/4012721.stm

Crown. (1996). Family Law Act 1996 (Chapter 27). Retrieved from http://www.hmso.gov.uk/acts/ acts1996/1996027.htm

Crown. (2003, November). Increasing safe accommodation choices for women and children. Retrieved from http://www.womenandequalityunit.gov.uk/domestic_violence/accommodation.htm

Crown. (2005). Explanatory notes to Domestic Violence, Crime and Victims Bill. London: Queen's Printer of Acts of Parliament.

Hanmer, J., \& Griffiths, S. (2000). Reducing domestic violence ... what works? Policing domestic violence. Crime Reduction Series, Home Office.

Home Affairs. (1990). Circular 60/90, Domestic violence. London: Her Majesty's Stationery Office.

Home Office. (1999). Domestic violence: Findings from a new British Crime Survey self-completion questionnaire. London: Home Office. 
Home Office. (2000a). Break the chain: Multi-agency guidance for addressing domestic violence. London: Home Office.

Home Office. (2000b). Domestic violence: Revised circular to police (Home Office Circular No. 19/ 2000). London: Home Office.

Home Office. (2001). The British Crime Survey: England and Wales. London: Home Office.

Home Office. (2003). Safety and justice: The Government's proposals on domestic violence (Cm 5847). London: Home Office. Retrieved from http://www.crimereduction.gov.uk/domesticviolence 37.htm

Hyder, K., \& Cowan, R. (2004, December 31). Yard's anti-domestic violence initiative. The Guardian. Retrieved from http://www.guardian.co.uk/crime/article/0,2763,1381169,00.html

Parmar, A., Sampson, A., \& Diamond, A. (2005). Tackling domestic violence: Providing advocacy and support to survivors of domestic violence. London: Home Office.

Seymour, J. (2002). Domestic violence against British women. Contemporary Review, 280(1633), 83-85.

Stanko, E. (2000). The day to count: A snapshot of the impact of domestic violence in the UK. Criminal Justice, 1(2).

Walby, S. (2004). Cost of domestic violence. Women \& Equality Unit. London: DTI Publications.

Women \& Equality Unit. (2004). Domestic violence. Retrieved from http://www.womenandequalityunit. gov.uk/domestic_violence/

Women's Aid Federation of England. (2004a). Protection under housing law. Retrieved from http:// www.womensaid.org.uk/policy\&consultations/rights\%20under\%20housing.htm

Women's Aid Federation of England. (2004b). Protection from violence under the civil law. Retrieved from http://www.womensaid.org.uk/policy\&consultations/rights\%20under\%20 civil\%20law.htm

Women's Aid Federation of England. (2004c). Protection under criminal law. Retrieved from http:// www.womensaid.org.uk/policy\&consultations/rights\%20under\%20criminal\%20law.htm

Women's Aid Federation of England. (2004d). About Women's Aid. Retrieved from http:// www.womensaid.org.uk/about/about_wafe.htm 